\title{
1. Identity-based constitutional claims: negotiating with regionalists
}

\section{INTRODUCTION}

This chapter discusses constitutional claims proposed by national identities. Constitutional debates over the roles of national identities are traditionally associated with the protection of minority rights. However, there is perhaps a larger group of constitutional demands that is fostered by identity groups. These identity-based constitutional claims are organized into a constitutional programme by an institution with a democratic mandate (for example, by a political party in a state or by a government in an international organization). The programme normally includes 'a path for constitutional recognition' of the distinctiveness of a nationalidentity group within the state. So the aim of this section of the book is to clarify the distinctive status of identity-based constitutional demands in modern and pluralist constitutional theory by explaining that some of the objections against their recognition are unfounded. ${ }^{1}$ In particular, I argue that constitutional programmes proposed by national identities should not be rejected in advance by advocating the irrational foundations of nationalism ${ }^{2}$ or by associating identity-based constitutional claims with the history of the ideology. ${ }^{3}$ Both objections are unfounded. They confuse, albeit at different levels of their respective critiques, an assessment of the reasons for the existence of a national community (whether it be religious, historical or political) with a deliberative evaluation of group constitutional claims. I will contend that a modern constitutional

\footnotetext{
1 David Haljan, Constitutionalising Secession (Hart 2014).

2 See, eg, Claus Offe, 'Homogeneity and Constitutional Democracy: Coping with Identity Conflicts through Group Rights' (1998) 6 Journal of Political Philosophy 113.

3 See, eg, Jürgen Habermas, 'Citizenship and National Identity: Some Reflections on the Future of Europe,' (1992) 12 (1) Praxis International 1. Vito Breda, 'The Incoherence of the Patriotic State: A Critique of Constitutional Patriotism' (2004) 10 Res Publica 247.
} 
system that aspires to create a set of communal alliances between strangers should seek to retrieve rational discourses, not to impose them.

The chapter is divided into two parts. The first part addresses the normative case against assessing identity-based constitutional claims and argues that a great level of enrichment might be achieved from inserting normative arguments into the debate over the procedural requirements of modern constitutions. The second part looks at the interplay between the development of the modern republican tradition and national identity.

\section{A METHODOLOGICAL OVERVIEW}

In the past three decades, identity-based constitutional claims have become more common, but their implications have not been fully researched. The Māori Party in New Zealand, the Catalonian Socialists in Spain, Parti Québécois in Canada and the Lega Nord in Italy rally their supporters around a programme of proposed constitutional reforms. ${ }^{4}$ Whilst the great majority of these reforms aim to readjust the balance of constitutional recognition for a particular community, a minority of these political parties such as the Scottish National Party (SNP) and a coalition of Catalonian political parties seek independence for their respective nations. ${ }^{5}$ However, even the radical process of transformation suggested by the SNP requires a constitutional programme and, in its implementation stage, a series of international treaties. The recent separation of the former Czechoslovakian Republic is a reminder of the complexity of

4 Kerensa Johnston, 'Maori Legal Developments' (2017) New Zealand Law Review 131; Daniele Albertazzi and Duncan McDonnell, 'The Lega Nord Back in Government' (2010) 33 West European Politics 1318; Legislative proposal, pursuant to Section 2 [2] of the Regional Law of the 19th June 2014, n 15: 'Modalities and Contents for the Recognition for the Increase of Specific Forms of Autonomy for the Veneto Region, Pursuant to the Third Paragraph of Article 116 of the Constitution' 2017; Jean-François Caron, 'The Exclusive Nature of Quebec's Contemporary Nationalism: The Pitfalls of Civic Nationalism' (2014) 47 International Journal of Canadian Studies 221; Robert Hazell, Devolution and the Future of the Union (The Constitution Unit 2015); Elisenda Casanas Adam, 'The Referendum on Catalonian Independence: The Position of the Catalan Authorities' https://ukconstitutionallaw.org/2017/10/03/elisenda-casanas-adam-thereferendum-on-catalonian-independence-the-position-of-the-catalan-authorities/ (accessed 4 January 2018); Kathryn Nalani Setsuko Hong, 'Understanding Native Hawaiian Rights: Mistakes and Consequences of Rice v. Cayetano’ (2008) 15 Asian Am. LJ 9.

5 SNP, 'Manifesto (2017)'; Casanas Adam (n 4). 
the internal and international procedures required to disentangle (without violence) two ethnic communities. At the international level, it is the increasing power of international organizations that worries national identities. For instance, an analysis of the documents considered by the European Constitutional Convention shows a plurality of perceptions regarding what a constitution should protect in terms of national cultural diversity, and what should be ignored for the benefit of the common good. 6

The deliberative process during the making of the un-ratified Treaty for a Constitution for Europe was also an occasion for discussing the principle of constitutional sovereignty. However, this debate needs to be distinguished from the debate regarding the protection of national identities as a hindrance to the European Union's (EU's) integrating project. Concerns based on the protection of a national identity were dismissed by two distinctive narratives. The first advocated separation between (European) constitutional law and national identity; ${ }^{7}$ the second argument suggested, instead, endorsing the concept of the 'nation' as the most attractive channel of institutional self-identification for a European Federation. ${ }^{8}$ This process had limited success in the United Kingdom of Great Britain and Northern Ireland (hereafter the UK or Britain). ${ }^{9}$

In this chapter and the ones that follow, I will explain how identitybased constitutional claims (within the limits of democratic reasonableness) could be considered a helpful expression of democratic dissent, and therefore silencing them might hinder the perceived democratic coherence of a constitutional system. Before turning to the development of my argument, I must set a series of terminological and methodological qualifications. The term 'national identity' is descriptive of a sociological phenomenon. The paper will refer to national identity as inclusive of both

6 Vito Breda, 'A European Constitution in a Multinational Europe or a Multinational Constitution for Europe?' (2006) 12(3) European Law Journal 330; Ailsa Henderson and others, 'England, Englishness and Brexit' (2016) 87 The Political Quarterly 187.

7 Jürgen Habermas, 'The European Nation-State. Its Achievements and its Limitations. On the Past and Future of Sovereignty and Citizenship' (1996) 9(2) Ratio Juris 125; Jürgen Habermas, 'Citizenship and National Identity: Some Reflections on the Future of Europe' (n 3).

8 Prodi's suggestion of a European 'melting pot' cannot be considered an alternative since it displaces the national identity with a European national identity. Specifically, he does not explain why we should prefer European common cultural national identity to the nation-state identity. Romano Prodi, Europe as I See It (Polity Press 2000) 4.

9 Henderson and others (n 6). 
civic nationalism - the form of nationalism easily tolerated in most modern democracies - and ethnocentric nationalism - which might be democratically problematic. ${ }^{10}$

I will use the term 'constitutional principles' to refer to those principles that discover, engage and deal with political claims in a way that a constituency considers reasonably acceptable. The concept is inspired by Habermas's early idea of communicative democracy. Some constitutional principles are equality for those who intervene in a public debate, the openness of the debate and the acceptance of reason. ${ }^{11}$

The role of national identity and identity-based constitutional demands in modern constitutional systems is charged with political tension. ${ }^{12}$

10 There is also the pragmatic difficulty of distinguishing the two because most national identities have blended (civic and ethnic) aspirations. For a general analysis of how sociologists distinguish the different stages (tribal, ethnocentric, multicentric) of development of nationalism, see Anthony D Smith, Theories of Nationalism (Duckworth 1971); Anthony D Smith, Nationalism: Theory, Ideology, History (Polity Press 2001).

Anthropological accounts tend to focus more on languages and how official languages shaped a national identity by creating out of thin air a communal civic conscience: Benedict Anderson, Imagined Communities: Reflections on the Origin and Spread of Nationalism (Verso 1983). Political studies tend to suggest instead a putative definition of the separation between civic and ethnic: Margaret Canovan, 'Patriotism is not Enough' (2000) 30 British Journal of Political Science 413; Yael Tamir, Liberal Nationalism (Princeton University Press 1993). Constitutional theorists tend to adopt a less prescriptive view of the social phenomenon. See, eg, how different narratives are developed in the UK: Robert Hazell, The English Question, Devolution Series (Manchester University Press 2006); Neil MacCormick, Can Nationalism Be Intellectually Respectable? (Oxford University Press 1991); Neil MacCormick 'The English Constitution, the British State and the Scottish Anomaly' (1998) 25 Scottish Affairs 129.

11 Habermas developed his modern deliberative democracy from his critical analysis over several years. Jürgen Habermas, Between Facts and Norms: Contributions to a Discourse Theory of Law and Democracy (Polity Press 1996); Jürgen Habermas, Toward a Rational Society: Student Protest, Science and Politics (Heinemann Educational 1971); Jürgen Habermas, The Theory of Communicative Action (Heinemann Educational 1984).

12 Javier García Oliva, 'Javier Garcia Oliva: The Referendum on Catalonian Independence: The Position of the Spanish Authorities' https://ukconstitutional law.org/2017/10/03/javier-garcia-oliva-the-referendum-on-catalonian-independencethe-position-of-the-spanish-authorities/ (accessed 4 January 2018); 'Javier García Oliva: Catalonia in Spain? The Future Ahead' https://ukconstitutionallaw.org/ 2014/11/10/javier-garcia-oliva-catalonia-in-spain-the-future-ahead/ (accessed 4 January 2018); Vito Breda, 'La Devolution de Escocia y El Referéndum de 2014: Cuáles Son Las Repercusiones Potenciales En España?’ [2013] Teoria y Realidad 
Arguing that national-identity constitutional claims should be individually assessed by a process of deliberation (and therefore not constrained by a superimposed system of norms/criteria) might be misread as a plea for considering national-identity claims as normatively 'worthy' of substantive recognition. They are not. At the theoretical level, a polity should generate a sense of solidarity and alliance among its members by discussing their aspirations without any reference to identity, gender, sexual preference and so on. Haljan, for instance, calls this sense of participation associative constitutionalism. ${ }^{13}$ However, claims are often drawn from a sense of belonging to a group (for example, a perception of a necessary relationship between faith and constitutional law) or where the national identity is the political conveyer of economic concerns (for example, the preoccupations generated by excessive immigration). The aspirations of creating an ideal, culturally neutral constitutional polity cannot prevent these debates from generating constitutional norms. ${ }^{14}$

The desire for a separation between constitutional principles and the political underpinnings of constitutional principles (for example, the liberal free market adopted in Europe and many modern Western-style democracies) has important epistemic implications for constitutional theory. For instance, direct discriminatory political claims (for example,

Constitucional 69; Scottish Goverment, Your Scotland, Your Referendum. Time Table to 2014 (2012); Kimberly A Costello, 'Rice v. Cayetano: Trouble in Paradise for Native Hawaiians Claiming Special Relationship Status Notes' (2000) 79 North Carolina Law Review 812; Haljan (n 1).

13 Haljan (n 1) 50-63.

14 Hazell (n 4); Henderson and others (n 6); Johnston (n 4); Albertazzi and McDonnell (n 4); Paul Williams and others, 'The Legitimacy of Catalonia's Exercise of its Right to Decide: A Report by a Commission of International Experts' (Global Studies Institute University of Geneva - Departament d'Afers i Relacions Institucionals i Exteriors i Transparència 2017) http://exteriors.gencat. cat/web/.content/00_ACTUALITAT/notes_context/FULL-REPORT-Cataloniaslegitimate-right-to-decide.pdf (accessed 21 April 2018); Richard Wyn Jones and Roger Scully, Wales Says Yes: Devolution and the 2011 Welsh Referendum (University of Wales Press 2012); Gregory Ablavsky, "With the Indian Tribes": Race, Citizenship, and Original Constitutional Meanings' (Social Science Research Network 2017) SSRN Scholarly Paper ID 3082038, https:// papers.ssrn.com/abstract=3082038 (accessed 2 January 2018); Antony Hooper, "Tokelau: A Sort of "Self-Governing" Sort of "Colony"' (2008) 43 The Journal of Pacific History 331; Scottish Goverment (n 12). 
British jobs for British workers) ${ }^{15}$ might logically have little legal traction in the EU. However, the assumption that European institutions or any modern state's institutions, by way of comparison with some nationalist political parties, are culturally neutral is equally misleading. ${ }^{16}$

The last theoretical stance is imprecise because it fails to acknowledge the dynamic nature of the constitutional qualification of principles such as equality, freedom and democracy, against which identity claims are made. It is the process of parliamentary deliberation (coupled in common law countries with jurisprudential qualification) that relentlessly fills constitutional principles with actual significance. Cultural neutrality is either proposed at the expense of the prerogative given to each individual to challenge the democratic coherence of constitutional norms ${ }^{17}$ or by setting an intersubjective (often unquestioned) set of values. The assumption in this book is that if normative prescriptions can be constructed as immutable ideals, constitutional principles ought to be discovered by a process of dialectical refinement within a distinctive constituency (in civil law systems) and/or discovery (in common law countries). It is this 'dynamic variability' of constitutional principles that prevents a selective reading of identity-based constitutional claims and that promotes the idea of a constitutional polity that works in partnership with national identities.

I will refer to the term 'cosmopolitanism' as the intellectual movement that forecasts and/or argues for establishing a global society without nation-states. The term is inclusive of the theoretical submission of Habermas that speculates about a boundless, open deliberative democracy and a forthcoming global order. ${ }^{18}$ It also includes the deductive analyses of, for instance, Held, who predicts the collapse of the nationstate as a side effect of an ever-expanding global economy and its international organizations. ${ }^{19}$

15 Gordon Brown, 'First Speech to the Labour Party Conference as Party Leader' (speech delivered at the 2007 New Labour Conference, Bournemouth UK, 24 September 2007).

16 Anthony D Smith, Nationalism: Theory, Ideology, History (Polity Press/ Blackwell 2001); Henderson and others (n 6); Jocelyn Maclure, Quebec Identity: The Challenge of Pluralism (McGill-Queen's University Press 2014).

17 Haljan (n 1) 51.

18 Jürgen Habermas, The Postnational Constellation: Political Essays (Polity Press 2001).

19 David Held, Democracy and the Global Order: From the Modern State to Cosmopolitan Governance (Polity Press 1995). 
The chapter is divided into two sections. The first section discusses whether the irrationality of nationalism as a political doctrine might provide an argument against all identity-based constitutional demands. This argument is developed as a response, firstly, to Offe's idea of egalitarian society, in which he appears to argue that there should be little space for identity-based constitutional demands. It is also a response to Habermas's theory of constitutional patriotism, in which the concept of national identities is considered an irrational doctrine that has no right to intervene in a constitutional debate. It will be argued that the internal incoherence of a political stance might not prevent a national identity from making reasonable constitutional demands. The second part of the chapter focuses, conversely, on the argument that considers identitybased constitutional demands to be historically incompatible with modern republican tradition. I will refer to this stance as the republican/historical critique, and I will argue that it confuses the historical process that formed the present conception of the nation-state (for example, the process of imperial decolonization) with its republican constitutional achievements.

\section{THE NORMATIVE CASE AGAINST NATIONALISM: TWO CRITIQUES}

Normative critiques of identity-based constitutional claims hold that these claims must not find their way into an ideal constitutional system. The argument against identity-based constitutional claims is, in general, well articulated and goes a long way towards finding a reason for excluding national-identity claims from a democratic arena, ${ }^{20}$ but its conclusions are unsound. The aim of a constitutional system, I argue, is to retrieve the rational validity of a claim (by way of democratically discussing it), not to exclude political parties and/or to police constitutional debates.

The normative case against nationalism is drawn from the assumption that identity-based claims are based on an ideology that is philosophically rooted in the misinterpretation of a Kantian philosophy. ${ }^{21}$ If the

20 A methodologically similar critical analysis is drawn from a liberal conception of modern state in Stephen Tierney, Constitutional Law and National Pluralism (Oxford University Press 2004) 52.

21 Jürgen Habermas, 'The European Nation-State: Its Achievements and its Limitations. On the Past and Future of Sovereignty and Citizenship' in Pablo De Grieff (ed), The Inclusion of the Other: Studies in Political Theory (MIT Press 1998); Michael Rosenfeld, 'Rethinking Constitutional Ordering in an Era of 
complexity and nuances of nationalist narratives are reduced to a set of crude deductions then an individual is free if she/he acts in accordance with communally accepted moral prescriptions. Because of that assumption, it is the imperative duty of every individual to strive and/or to protect a communal freedom, namely the self-determination of the nation. An early historical example of a nationalist narrative that combines the right of individual freedom with communal destiny might be found in the Declaration of Arbroath (1320 AD): '[a]s long as a hundred of us remain alive, never will we on any conditions be subjected to the lordship of the English. It is in truth not for glory, nor riches, nor honours that we are fighting, but for freedom alone, which no honest man gives up but with life itself'. ${ }^{22}$ The Declaration of Arbroath was an early attempt to establish a link between individual freedom and national self-determination. Nonetheless, from a normative perspective, the boundaries between the individual and the communal rights of selfdetermination are not easy to retrieve.

However, in constitutional theory, two specific perspectives engage the normative unsteadiness of identity-based constitutional claims. Firstly, constitutional norms must refer to universal and absolute moral principles; ${ }^{23}$ secondly, the right to individual self-determination has a mainly procedural function in the process aimed at finding those principles (that is, individuals must be free to engage in a debate over what freedom means). The philosophical persuasiveness of these two critiques is conceded; however, I argue that they do not have the same valence in modern constitutional theory.

From a constitutional perspective, the process of normative discovery, that is perhaps part of the enlightened project, is procedurally different from the practices that qualify the valence of constitutional claims in an indirect democracy. I draw this distinction from Tully's analysis of the relations between ancient and modern democracies. ${ }^{24}$ Deliberative practices in ancient democracy, with some important qualifications such as

Legal and Ideological Pluralism' (2008) 6(2) International Journal of Constitutional Law 415.

22 Translation of the Declaration of Arbroath based on Sir James Fergusson, The Declaration of Arbroath 1320 (1970) 5-11, with reference to A A M Duncan, 'The Nation of Scots and the Declaration of Arbroath' (Historical Association pamphlet, 1970) 34-37 and D E R Watt (ed), Scotichronicon Vol. 7 (Edinburgh University Press 1996) 4-9.

23 Offe (n 2).

24 James Tully, 'The Unfreedom of the Moderns in Comparison to Their Ideals of Constitutional Democracy' (2002) 65(2) Modern Law Review 204. 
gender and class discrimination, might be considered proxies for a potential common enlightenment and the discovery of normatively poignant principles.

Modern constitutional democracy, in contrast with ancient democracy, is dependent on procedural rules that channel political claims into parliaments and constitutional conventions. One key role of these procedures is to reduce the risk of restricting the admissibility of political claims beyond a level of reasonableness and to transform a constitutional democracy into a self-referential system that reproduces previous decisions rather than to democratically assess constitutional claims. ${ }^{25}$ It is from such an awareness of the implications of restricting the role of identity groups that this book calls for an open assessment of identitybased constitutional claims.

The argument is not only that constitutional rules have to be conventionally posited (for example, constructed in clear, general terms), and that necessity should trump political and moral discourses (identity-based constitutional claims are part of all of the legal systems considered in this book), but also that constitutional theories should not downplay the important role of democratic procedures in modern democratic systems. However, the universal/particular critique and the relentless reference to the irrationality of national identity appear to insert a procedural limitation on modern democracy. That is, identity-based constitutional demands are not worth discussing by default, so to speak, because national identities are the political manifestation of an incongruent doctrine. This position is democratically incoherent.

25 Four authors have developed the epistemic implication of Tully's work in their own narratives: Zoran Oklopcic, 'Constitutional (Re)Vision: Sovereign Peoples, New Constituent Powers, and the Formation of Constitutional Orders in the Balkans' (2012) 19 Constellations 81; Martin Loughlin, 'Reflection on the Idea of Public Law' in Emilios Christodoulidis and Stephen Tierney (eds), Public Law and Politics: The Scope and Limits of Constitutionalism (Ashgate 2008) 47-68; Frank Michelman, 'Constitutionalism as Proceduralism: A Glance at the Terrain' in Emilios A Christodoulidis and Stephen Tierney (eds), Public Law and Politics: The Scope and Limits of Constitutionalism (Ashgate 2008) 69. A general overview of the issue of the self-referential aspect of law is provided in Hans Lindahl, 'Democracy, Political Reflexivity and Bounded Dialogues: Reconsidering the Monism-Pluralism Debate' in Emilios A Christodoulidis and Stephen Tierney (eds), Public Law and Politics: The Scope and Limits of Constitutionalism (Ashgate 2008) 103-117. Hans Lindahl, 'Democracy , Political Reflexivity and Bounded Dialogues: Reconsidering the Monism-Pluralism Debate' in Emilios A Christodoulidis and Stephen Tierney (eds), Public Law and Politics: The Scope and Limits of Constitutionalism (Ashgate 2008) vi. 


\section{The Universal/Particular Critique}

The first normative critique against identity-based constitutional claims argues that there is a paradoxical relationship between identity demands and the universal aspiration of constitutional norms. For instance, the refusal to consider (even the refusal to recognize) regional-identity groups as proxies for constitutional demands should be the default stance in an egalitarian society. ${ }^{26} \mathrm{~A}$ similar narrative is also in Haljan. ${ }^{27}$

It is so, Offe argues, for good reasons. Identity-based constitutional claims are very difficult to substantiate because they are derived from dogmatic assumptions such as a right to be treated differently. However, the prima facie incongruity of some identity-based claims (for example, we have a right over this land because a deity told us that we are different) does not prevent democratic debates that encourage mediation between normative principles (for example, equality) and a political stance. ${ }^{28}$ For instance, the SNP has led an open consultation, called the National Conversation, aimed at testing the possible financial and institutional aspirations of Scotland's future. ${ }^{29}$

The plan led to a consultative referendum on independence. ${ }^{30}$ The Scottish aspirations of autonomy could be considered antithetical to Offe's idea of an egalitarian society. Nevertheless, if analysed in detail, the National Conversation and the consultation for a referendum concerning Scotland's independence promote a political dialogue via a series of initiatives that have, for instance, raised awareness of a distinctive Scottish constitutional history, produced a number of documents concerning policies and that have received substantial backing by the independent Commission on Scottish Devolution. Although debate over the referendum on independence led to a great deal of tension between the

26 James Tully, Strange Multiplicity: Constitutionalism in an Age of Diversity, The John Robert Seeley Lectures 1994 (Cambridge University Press 1995) Ch 2.

27 Haljan (n 1) 204.

28 This point is analysed by Rosenfeld. See in particular Chapters 2 and 3 of Michel Rosenfeld, The Identity of the Constitutional Subject (Routledge 2010).

29 The Scottish Executive, 'List of Contributions: Scotland's Future: A National Conversation' (2012) http://www.scotland.gov.uk/Topics/a-nationalconversation/NC-contributions-inds-org.

30 'Agreement between the Scottish Government and the United Kingdom Government on the Referendum on Independence for Scotland' (2012) http://www. scotland.gov.uk/About/Government/concordats/Referendum-on-independence. 
Scottish and the UK parliaments, the result of the consultative referendum would not alter the UK's constitutional system (that prerogative remains with the UK parliament).

The consultative referendum is, instead, an opportunity given to Scottish residents to say whether the Scottish parliament should be given the 'powers' to enable negotiation over independence.

Offe's idea of egalitarian society appears to argue that these initiatives should be assessed against the principle of equality, yet this submission overlooks the antidemocratic implications of considering equality to be a procedural limit. A more pertinent observation would consider the Scottish bid for a referendum over national self-determination to be part of a democratic process that maintains the democratic coherence of a multinational polity such as the UK. Such a process cannot be restricted a priori by focusing on its normative implausibility or its outputs without questioning the democratic structure of the constitutional system.

Again, there is a tension generated around national-identity demands, and so I must be precise. The principle of equality that allows nationalidentity groups to intervene in constitutional debates should not be confused with an attempt to redeem nationalism or, even worse, to speculate on a substantive link between folk and constitutional norms. Regionalist political groups, such as the Lega Nord in Italy, are the institutional proxy for constitutional demands that might be in logical opposition to an egalitarian society.

For instance, the implementation of the Italian 2001 constitutional reform (ex art 119 of the Italian constitution) promoted by the Lega Nord entrenches economic disparity between the North and South of Italy. ${ }^{31}$ In this case, Offe's critique inspires a helpful narrative, given that it reminds all those involved in a constitutional debate of the logical limits of political demands in a constitutional polity that endorses the principle of equality (ex art 3 of the Italian constitution). However, the principle of equality cannot prohibit arguments that demand adjustments to the allocation of public resources (for example, infrastructure) if such an allocation better matches the needs of heavily industrialized areas in the north. ${ }^{32}$

31 Luca Antonini, Federalismo all'italiana (Marsilio 2013); Francesco Palermo, 'Italy: A Federal Country without Federalism?' in Michael Burgess and G Alan Tarr (eds), Constitutional Dynamics in Federal Systems: Sub-National Perspectives (McGill-Queen's University Press 2012).

32 Emma Lantschner, 'History of the South Tyrol Conflict and its Settlement' in Jens Woelk, Francesco Palermo and Joseph Marko (eds), Tolerance Through Law: Self Governance and Group Rights in South Tyrol (Brill 2007). 
The argument is that the principle of equality demands reasonable limits on all political claims by projecting a limit, we might say a floodgate, on the effects of those claims (for example, avoidance of groundless discriminatory demands) on a polity. However, those procedural limitations do not sustain Offe's demand for a preventive assessment of the 'normative worthiness' of identity-based constitutional claims.

\section{The Irrationality of Identity-Based Constitutional Claims}

In the previous section, we dwelt on the normative critique, and I suggested that there is a procedural incompatibility within identity-based constitutional claims that starts or continues a political project by implying the superiority of one identity group over another. However, I argued that such procedural limits do not prevent the admissibility of all identity-based constitutional claims. Even without considering constitutional systems that are designed to be decentralized, Offe's critique supports a substantive understanding of the principle of equality that is at odds with the normative requirement for a modern constitutional polity to have democratic openness.

In this section, I will dwell, instead, on a second critique of the role of identity-based claims, one that denounces the internal incoherence of nationalism as a political doctrine. The internal critique holds that nationalists confuse the Kantian idea of individual freedom with a national right of self-determination. The focus of this internal critique is on the lack of normative links between the two rights.

I will argue that a debate concerning the existence of a link between individual and national rights of self-determination might clarify the relationship (or lack thereof) between the two but should not support the exclusion of identity-based groups from a constitutional system. Specifically, I suggest that internal incoherencies of identity-based constitutional claims might logically limit their persuasiveness, but not substantively reduce their admissibility, in constitutional dialogues. Before going further, it might be useful to note how the right of self-determination of groups is a principle recognized by international institutions and state constitutions. The 1945 Charter of the United Nations, for instance, asserts that the purpose of the United Nations is 'To develop friendly relations among nations based on respect for the principle of equal rights and self-determination of peoples, and to take other appropriate measures to strengthen universal peace'. ${ }^{33}$ A similar assertion can be found in the

33 United Nations, Charter of the United Nations and Statute of the International Court of Justice, UNTS XVI (24 October 1945). Art 1 [2]. 
1957 Treaty of Rome, which set the foundations for today's EU: 'DETERMINED to lay the foundations of an ever-closer union among the peoples of Europe'. ${ }^{34}$ The assertion of a right to be a self-determinate national population is also part of many post-Second World War constitutions. For instance, La Constitution du 4 October 1958 ('French constitution') states that 'The French people solemnly proclaim their attachment to the Rights of Man and the principles of national sovereignty as defined by the Declaration of 1789'. ${ }^{35}$ However, enthusiasm for the legal and/or constitutional right of self-determination was not echoed in political theory. In particular, a very strong critique against identitybased communal rights was developed at the end of the Second World War by authors who saw and/or directly experienced the pathological effects of the right of self-determination of the nation. Back then, Kedourie argued that nationalists misinterpreted the underpinning premises of Kant's philosophy and associated the concept of the nation with the idea of a common moral community. ${ }^{36}$

In contrast with the model of governance provided by the Empire, which nationalists perceive as amoral, the self-determination of the nation is a vessel for the development of a national democratic culture. Nationalists argue that the web of cultural relations between people that underpins the political and administrative structure of the state has a twofold effect on the legal system. Firstly, it is a source of democratic and moral legitimacy for the state. Secondly, it provides a criterion (for example, the ability to speak the national idiom) for distinguishing members of the national community from aliens. ${ }^{37}$

There are few doubts about the internal incongruence of this assumption and its tragic historical consequences. Certainly, the post-war case against the right to national self-determination is rhetorically powerful (there is strong evidence associating nationalism with discrimination) and, to a great extent, convincing. There is a plethora of nationalist

34 Treaty Establishing the European Economic Community, opened for signature 25 March 1957, 298 UNTS 11 (entered into force 1 January 1958) 2 ('Treaty of Rome').

35 La Constitution du 4 Octobre 1958 [French Constitution of 4 October 1948] Preamble.

36 Elie Kedourie, Nationalism (Hutchinson 1960) 18.

37 Ibid 5: 'Nationalism is a doctrine invented in Europe at the beginning of the nineteenth century. [...] Briefly, the doctrine holds that humanity is naturally divided into nations, that nations are known by certain characteristics, which can be ascertained, and that the only legitimate type of government is national self-determination'. 
groups (for example, the Lega Nord) that make undemocratic claims. ${ }^{38}$ However, the dilemma is whether a modern template for a constitutional democracy requires an a priori rational test of the internal structure of any political doctrine. In addition, if the test fails, could claims made by supporters of that doctrine be prevented from entering the democratic arena? Theoretically, yes.

The assumption might be made, for instance, that in an ideal constitutional polity, only communal claims that bear some normative values (for example, economic benefits for the entire polity) deserve democratic recognition. However, there is still a great deal of disagreement over what an ideal legal system might look like and what substantive and procedural steps and practices will drive us in the direction of such an ideal constitutional polity.

By way of comparison, there is more consent among constitutional theorists regarding the role of democracy as an imperfect procedural system for retrieving rational decisions. We have seen, for instance, that Tully gleans from the distinction between indirect democracy (that is, modern democracy) and ancient democracy the idea that procedures allow norms to be questioned by all those affected. ${ }^{39}$ It is from this perspective that the internal critique of the nation-state may appear less convincing.

For instance, let us assume that the 2005 French referendum that rejected the Treaty to Establish a Constitution for Europe is an exclusive expression of the right of self-determination of the French people entrenched in the preamble of the 1958 French constitution and that the UK's Brexit referendum is an expression of a narrow-minded perception of the common good. ${ }^{40}$ These rejections might be considered incoherent as an exclusive expression of national self-determination and, thus, normatively irrational. The dilemma is whether the irrationality that motivated such a democratic expression could also be considered a reason for flaunting the result of the referendum. The answer is in the

38 James Tully, 'The Challenge of Reimagining Citizenship and Belonging in Multicultural and Multinational Societies' in Catriona McKinnon and Iain Hampsher-Monk (eds), The Demands of Citizenship (Continuum 2000); Tully (n 24). For a well-known analysis of the theoretical feasibility of an ideal constitutional polity (that follows his Theory of Justice) see, eg, John Rawls, Political Liberalism (Columbia University Press 1993).

39 Tully (n 24).

40 Henderson and others (n 6). 
negative ${ }^{41}$ Again, the argument here is not that the "nationalist will of the French people or the British' has to be respected because it is legally recognized by the French constitution and international organizations such as the EU, or because they are in compliance with UK statutes. Rather, we should assume that, in a modern indirect democracy, we cannot impose stringent limitations on the reasons that support a claim.

However, recent proposals appear to have rediscovered the stance that, first, denounces the internal incoherence of nationalism as a political doctrine and then 'muddles' the distinction between constitutional and normative assessments of identity-based constitutional claims. Habermas, for instance, argues that a substantive and direct relationship between the idea of a homogeneous national population and the state's right to self-determination is normatively unsupported. Habermas echoes Kedourie, saying that a claim for the right to self-determination of the nation can promote a policy of ethnic and racial persecution against minorities: 'The positive self-understanding of one's own nation now becomes an efficient mechanism for repudiating everything regarded as foreign, for devaluing other nations, and for excluding national, ethnic, and religious minorities, especially Jews' ${ }^{42}$ The link between nationalism and ethnocentrism is conceived. The national community must define the others to set its boundaries. However, in the quotation, Habermas appears to pursue Kedourie's idea a step further and suggests an explicit constitutional exclusion of nationalism from modern constitutional democracy: 'The nation-state must renounce the ambivalent potential [the linkage between it and nationalism] that once propelled it'. ${ }^{43}$ The idea of 'an in-advance exclusion' of nationalism from modern democracy and the endorsement of his idea of constitutional patriotism might be appealing to European elites ${ }^{44}$ for whom the association between the two might be seen as one of the major obstacles to a fully integrated EU. Nonetheless, the argument suggests a great limitation on the reasons that drive a constitutional polity.

For instance, if we were to regard the EU as the most likely laboratory for a patriotic state, a series of dilemmas would need careful consideration. Firstly, is the mere risk of an exclusive stance by a nation that is heavily invested with a particular view of itself as ethnically homogenous

41 James Tully, 'A New Kind of Europe?: Democratic Integration in the European Union' (2007) 10 Critical Review of International Social and Political Philosophy 71 .

42 Jürgen Habermas, Between Facts and Norms (n 11), 111.

43 Ibid 117.

44 Breda (n 3). 
a danger that requires nationalism to be excluded entirely? Secondly, even if the nation-states relinquished their egoist perspective of creating a patriotic state, what would be the guarantee that EU institutions would not develop their own European ethnocentric national identity? Are not those references to European humanism in the preamble of the failed Constitution for Europe a manifestation of a nationalism (very similar to Smith's polycentric nationalism $)^{45}$ that might limit the democratic openness of constitutional debates?

We might speculate that Habermas's purpose is less radical than it appears and that we are constructing rhetorical 'straw men'. This is, for instance, the interpretation suggested by Müller. ${ }^{46}$ Müller holds a less radical interpretation of Habermas's historical account, one that disfranchises some of the normative implications of his critique of the nationstate. Müller starts by questioning the consistency of the English translation of Habermas's works and suggests, for instance, an interpretation of constitutional patriotism in tune with a dynamic cosmopolitan democracy. However, the use of terms such as 'must' (in the English translation) might need further clarification in order for these words to escape their prima facie normative charge. ${ }^{47}$

Still, a second reading suggests that, in his idea of constitutional patriotism, Habermas's critique of nationalism stretches the logical internal requirements of a constitutional narrative into an assessment of a political stance. ${ }^{48}$ For Habermas, a constitutional system is not a mere executor of normative prescriptions but works as a conveyor of moral demands that have transcended historical political discussion and found their way into constitutional prescriptions. For instance, many aspects of the doctrine of human rights are perceived by Europeans as evidence of a common apolitical inheritance. It is from this common tradition that Habermas appears to extract an in-advance exclusion (what we might call an a priori exclusion) of identity-based constitutional claims from the political arena. Put simply, we have to exclude identity-based constitutional claims because that is a lesson that our forebears taught us.

\footnotetext{
45 Anthony D Smith (ed), Ethnicity and Nationalism (Brill 1992).

46 Jan-Werner Müller, 'On the Origins of Constitutional Patriotism' (2006) 5 Contemporary Political Theory 278. See also Pablo De Greiff, 'Habermas on Nationalism and Cosmopolitanism' (2002) 15(4) Ratio Juris 418.

47 Vito Breda, 'Constitutional Patriotism' in Mortimer Sellers and Stephan Kirste (eds), Encyclopedia of the Philosophy of Law and Social Philosophy (Springer 2017).

48 Ibid.
} 
This conclusion cannot be accepted - again, not because we live in a world dominated by nationalist, self-determined democracies and thus a 'contingent state of affairs trumps normative reasoning', but because the irrational internal structure of nationalism-based communities is unrelated to the functioning of a deliberative arena in an ideal constitutional polity.

Specifically, Habermas should consider that civic cohesion in a patriotic sense, that is, the attachment of a system of constitutional values perceived to be worthwhile, should spring from an inherited system of values and a dynamic process of democratic deliberation that relentlessly adjusts those values. There are positive and negative implications of recognizing the dynamic nature of republican values. One positive consequence is the development of a process that relentlessly seeks to adjust the perception of normative validity to a specific situation. Habermas's early critique of liberal democracy has been, perhaps, one of the most lucid reminders of the importance of democratic dissent as a procedural building block of modern open society. 49 The negative implication is that antidemocratic political claims (and we know that identity-based constitutional claims such as the one by the Lega Nord in Italy are at odds with the idea of an egalitarian society) might collect enough political capital to seriously restrict the process of democratic deliberation. ${ }^{50}$

However, restricting a priori the admissibility of identity-based claims because they do not fit the pre-existing set of republican values is derived from the conclusion that in debates about national identity, we have to find the optimal balance between openness and the protection of civic virtues. This is not very convincing. I share Habermas's unease about the potentially dangerous implications of a revival of regionalism and nationalism, and indeed, we can retrieve from a republican tradition a series of persuasive arguments, but we cannot prevent identity-based claims from entering constitutional debates at the state level and/or in international organizations such as the EU.

The motivations that support the attempt are admirable, that is the prevention of discriminatory policies, but the reasoning attracts critiques

49 The critical contributions of Habermas are developed in Jürgen Habermas, Toward a Rational Society (n 11); Jürgen Habermas, The Structural Transformation of the Public Sphere: An Inquiry into a Category of Bourgeois Society (Polity Press 1989).

50 Patrik Macklem, 'Militant Democracy, Legal Pluralism, and the Paradox of Self-Determination' (2006) 4(3) International Journal of Constitutional Law 488. 
both from those who support, in principle, the idea of a global democracy and from nationalists. Those enthused by the idea of global democracy or, at this stage, a stateless European democracy, note the confusion between the aspiration for an open and culturally diversified cosmopolitan society and the imposition of a 'historically learned' republic version..$^{51}$ The debate that such a critique generates is concerned with what a cosmopolitan constitution ought to be (for example, should it defend humanism? $)^{52}$ and what it is that civil states should learn from their historical mistakes. ${ }^{53}$

The republicans consider, instead, a selective reading of the history of constitutional law, one that omits key historical developments of modern constitution making, that spans from the Declaration of Arbroath to the 1958 Charter of the United Nations via the US Declaration of Independence, in which the right of a people's self-determination is considered a key element of any political association.

\section{The Historically Learned Republican Critique}

The previous section discussed both the normative critique and the role of identity-based political claims in modern constitutional democracy. It has been argued that we cannot find a normative reason for the a priori exclusion of identity-based constitutional claims from a modern constitutional polity. The following section engages squarely with the epistemic error of the republican critique. Specifically, it discusses the republican historical rendering of modern constitutional democracy.

This section will argue that, whilst historical analyses might help us comprehend the present functioning of constitutional systems, a historical argument cannot support or negate a connection between state and identity. My argument here is that the republican achievements of modern constitutional democracy can be separated from the development of nationalism and, thus, that historical arguments in favour of (as supported

51 Breda (n 47); Robert Nichols and Jakeet Singh, Freedom and Democracy in an Imperial Context: Dialogues with James Tully (Routledge 2014); James Tully, 'The Unfreedom of the Moderns in Comparison to Their Ideals of Constitutional Democracy' (2002) 65 Modern Law Review 204.

52 P C J Lobeira, 'Is Europe Still Worth Fighting for? Allegiance, Identity and Integration paradigms revisited' in F. Jenkins, M. Nolan and K. Rubenstein (eds), Allegiance and Identity in a Globalised World (Cambridge University Press 2014)

53 Jan-Werner Müller, Constitutional Patriotism (Princeton University Press 2007) 38 . 
by nationalists) or against (proposed by republicans) a connection between state and nation are constructed with equal precariousness.

Modern constitutional democracy often favours a common language (for example, a set of idioms/symbols/codes that can be easily understood across cultures). The sharing of a common language, however, helps the expansion of nationalism as a political doctrine. ${ }^{54}$ However, the historical paths that favoured the establishment of modern democracy, on the one hand, and modern nationalism, on the other, can be logically separated.

There is no evidence, for instance, that multinational states (for example, the Swiss Confederation and the UK) are less democratic than ethnically homogenous polities (for example, Japan). ${ }^{55}$ As contended in the previous sections, nationalism is, and has been, a manifestation of a culturally diversified society that has, as with other sociological groups, historically influenced the understanding of constitutional values. An analysis of the distinctive historical developments of set constitutional principles, for instance, might supply further details about the comparative account of a constitutional system. However, the history of societal interaction with principles (the fact that, in the past, lawyers and politicians might interpret the same rules in different ways) does not support and/or preclude future constitutional recognition of claims made by identity groups.

The formation of the nation-state has followed three different paths. Some nation-states began when an already-established kingdom transformed its subjects into a quasi-uniform national population (for example, France). Others have been the result of intellectual campaigns conducted by romantic writers and poets against imperial powers (for example, Italy and Germany). Finally, some have been the result of a process of decolonization (for example, the USA, Australia, Canada and New Zealand). These three historical processes have led to some confusion over the historical development of nationalism and its role in modern constitutional democracy. ${ }^{56}$

Despite the nationalist rhetoric of some political parties and the historical fact that both constitutional democracy and nationalism expanded from Europe to the rest of the world during the same era, nationalism and the protection of republican values (for example, equality) should be considered distinct processes. There is strong evidence that, since the late eighteenth century, large-scale nation-states have

\footnotetext{
54 Maclure (n 16); Casanas Adam (n 4); Lantschner (n 32).

55 Ernest Gellner, Nations and Nationalism (Blackwell 1983).

56 Eric J Hobsbawm, Nations and Nationalism since 1780: Programme, Myth, Reality (Cambridge University Press 1990).
} 
developed in tandem with an increased concern for the protection of a set of republican principles. Ernest Gellner argues, for instance, that the identity-formation processes that shaped today's modern nation-states developed during the industrialization of Europe. ${ }^{57}$ Although the term 'nation' was used during the Middle Ages by universities and knight orders, the concept of a nation, Gellner explains, did not exist until the eighteenth century. In fact, it was during industrialization that modern states needed a reliable language. The adoption of a national language, in turn, stimulated the spread of nationalism.

The key features of the industrial era were constant development, social mobility and the need for a continuous increase in communication between different individuals (for example, high-society capital holders, middle-class professionals and labourers) who worked at different stages of the industrial process. Before industrialization, different classes could speak different languages without any detrimental effect on the economic or institutional efficiency of a state. For instance, most of the European nobility spoke French, intellectuals and the clergy spoke ancient Greek and Latin, and the lower classes spoke the local vernacular.

However, Gellner notes that the manipulation of goods in an industrialized society required the development of a common language. The distinctive side effect of communication across classes was the formation of a national standard idiom that was intelligible to all. The idiom that would become the nation-state's language was often selected based on its popularity among the middle classes. For instance, Italian, made popular by Dante's 'Divina Commedia', 58 was the vernacular spoken in the regions around Florence.

Having a common language had two consequences. The first was an increase in social mobility: gifted entrepreneurs who might have been from very poor backgrounds but who could speak the national language aspired to join the middle classes. Such an opportunity was historically unprecedented. The second consequence was that the move towards a more egalitarian society (vis-à-vis mediaeval society) favoured the perception that belonging to a community (which provided a common language) and to a modern state were synonymous. This misconception had a multifaceted impact on the relations between individuals who did not share anything apart from being arbitrarily included inside the same state's borders.

57 Ernest Gellner, Nations and Nationalism (n 55) 33. Similar narratives are in Anthony D Smith, Theories of Nationalism (n 10).

58 Dante Alighieri, La Divina Commedia (Italian edition) (Scrivere 2010). 
Firstly, the subjects of a given royal family became 'citizens'. Citizens would use a common language to express their equal status. Secondly, the national group chosen as the proxy for the nation language often perceived the values expressed in the constitution to be a manifestation of national (not republican) moral values. Such a perception is, Gellner argues, based on an imprecise historical narrative. There is a historical overlap between the modern state benefitting from having a common language and the development of an egalitarian society, yet the two are unrelated.

The dilemma for constitutional theorists is whether the nationalist claim of ownership of republican values, which is precariously constructed, should be prevented from entering into constitutional debates at a state level. The short answer is no. The perception that an identity is the historical repository of an idea (for example, equality) taken, perhaps, from a historical document (for example, the Magna Carta) should be separated from the process that accommodates these claims in a constitution.

For instance, MacCormick holds that the plurality of the national community provides the backdrop for developing different patterns of interpretations of commonly endorsed liberal principles in the UK constitutional system. MacCormick argues that the individual and group senses of freedom, which democracy provides, require a sense of loyalty regarding collective decisions - specifically, the acceptance of communal choices. MacCormick suggests that this is possible only if democracy takes into account the individual self-realization that depends on a substantial degree of economic and social support. 'It is clearly not possible to understand humans as extrinsically extra-social atoms who come together voluntarily or otherwise to form human societies or communities, in the manner envisaged by contractarian thought'. ${ }^{59}$ Developing this reasoning, MacCormick argues that the collective sense of belonging that supports democracy might be a proxy for a range of constitutional claims (for example, regional autonomy).

MacCormick's concept of identity-based constitutional claims is drawn from the historical accommodation of republican principles, but what is not clear is whether it is compatible with the basic values of a modern democratic society (for example, openness, the respect of pluralism and so on). To pre-empt this critique, he argues that democracy requires a sense of loyalty to collective decisions. Nationalism is one of these

59 Neil MacCormick, Questioning Sovereignty Law, State and Nation in the European Commonwealth (Oxford University Press 1999) 176. 
sociological phenomena that contribute to the process of assessing the valence of constitutional principles. ${ }^{60}$

MacCormick's suggestion is that some nationalist perceptions that link together institutions (regional, national and European) and cultural aspects (religion, language and cultural heritage) might be irrational as well as undemocratic. However, it is the process by which these perceptions are accommodated or rejected by a constitutional system that sustains a communal acceptance of constitutional principles.

The argument here is not that, in a context in which all democracies are nationalistic, identity-based constitutional claims are superior. MacCormick's argument instead seeks to explain the importance of a historical partnership between a national identity (for example, the one shared by Scottish public lawyers) and a system of values endorsed by a constitutional system. By starting from a historical analysis of the origin of the UK, he explains that there is a dialectical partnership between the development of the constitutional principle (for example, sovereignty and the rule of law) and UK national identities (British, English, Northern Irish, Scottish and Welsh). The dialectical partnership is, however, only one of the processes that helps maintain a communal acceptance of the values held in the UK constitutional system.

MacCormick's analysis focuses on the rule of law, but it also has general relevance. He explains that historical processes that have given a distinctive cultural qualification to a set of universal values in a society (for example, the Supreme Court's historical qualification of freedom of speech in the First Amendment to the US Constitution) and the entrenchment of nationalist symbols (for example, the colours of the 'Ensigns Armorial of the said United Kingdom be such as Her Majesty shall appoint and the Crosses of St Andrew and St George be conjoined in such manner as Her Majesty shall think fit' set in section 1 of the 1707 Act of Union) are not mutually exclusive. Instead, both processes (that is, the process of legal qualification of right and the assertion of partnership between the constitution and an identity) are asserting the people's ownership of a legal text that they perceive as fundamental for their political community.

$60 \quad$ Ibid 167. 


\section{CONCLUSION: ARGUMENTS FOR AND AGAINST IDENTITY-BASED CONSTITUTIONAL CLAIMS}

This chapter analysed the arguments that refuse to consider national identity as a proxy for constitutional claims. It was argued that a number of normative criticisms of identity-based constitutional claims are misconceived. Calls for a substantive implementation of the principle of equality confuse the logical limitations imposed on all political claims (for example, avoidance of groundless discriminatory demands) with the less stringent procedural limits of deliberative democracy. Habermas's normative critique is, instead, mis-shaped. It has been shown to rest on a misunderstanding of the partnership between civic cohesion in a patriotic sense (that is, the attachment to a system of virtues) and the deliberative process that adjusts those universal values to a specific society.

The second part of the chapter focused on the historical/republican critique of identity-based constitutional claims. The republican/historical case against identity-based constitutional claims and the idea of the nation-state is powerful, yet the role of these claims cannot be completely dismissed, as some critics suggest. Certainly, nationalist beliefs can be democratically dangerous and national-identity groups can be proxies for potentially undemocratic constitutional demands. However, a distinction must be made between the internal incongruence of nationalism as an overarching doctrine and the constitutional demands (for example, regional autonomy) proposed by those whom it inspires.

This chapter argues that the internal or historical oddities of nationalism might be difficult to accept but that there is no reason for a constitutional system to assess whether identity groups have or do not have an inherent moral right to promote constitutional claims. It has been argued that modern constitutional policies depend on deliberative activities aimed at retrieving or restoring rationality within a pluralist and dynamic constitutional polity rather than at imposing it.

The last section of this chapter has focused on seeking out a historical account that separates the development of the constitutional state and nationalism. Whilst the two can be historically and sociologically separated, the dilemma for constitutional theorists is whether the state has developed a republican tradition that independently protects the rule of law - for instance, from contributions made by national-identity groups. The short answer is no.

National identities have been considered one of a number of political proxies for the qualification of republican principles (for example, the protection of minorities) and cannot be distinguished from other groups' 
contributions. The idea that identity-based constitutional claims ought to be separated from a culturally neutral republican tradition is both implausible and democratically precarious. In the following chapter I will explain how identity-based constitutional claims are recognized and negotiated in a variety of legal systems. ${ }^{61}$

61 Parts of this chapter first appeared in: Vito Breda, 'An Odd Partnership: Identity-Based Constitutional Claims', in F. Jenkins, M. Nolan and K. Rubenstein (eds), Allegiance and Identity in a Globalised World (Cambridge University Press 2014) 52-76. 